\title{
SOME ASPECTS OF RESTORATION OF DEGRADATED SEWAGE RECEIVERS
}

\author{
Hubert Komorowski \\ Agnieszka Karczmarczyk \\ Józef Mosiej \\ Warsaw Agricultural University, Poland
}

\begin{abstract}
Bottom sediments are naturally connected with water body of the river and it is essential in pollutant balance. Natural phosphorus cycle in water environment is sedimentation cycle. Once introduced to water ecosystem can be removed by different chemical, biological and physical processes and loses its environmental mobility as a sediment component.

In studied case the contaminants load was radically reduced by construction of wastewater treatment plant in city of Lodz. But the water quality improvement was not commensurate to this reduction. Such situation could be the result of increased phosphorus release from sediments deposed in the course of decades in river bed. On the distance the phosphate concentration increases up to $25 \mathrm{~km}$ downstream the WWTP outlet and it can not be explained by other pollution sources. The phosphorus content in the sediment is as high as 27 $\mathrm{mg} \mathrm{kg}^{-1} \mathrm{dw}$. The equilibrium phosphate concentration (EPCo) experiment showed that it could be released to water body. The preliminary results showed that EPCo value exceed in some points limit polish water quality norm and amount to $1.2 \mathrm{mg} \mathrm{PO}_{4} \mathrm{dm}^{-3}$ in oxic condition.
\end{abstract}

\section{KEY WORDS}

Bottom sediments; Reclamation; Equilibrium phosphate concentration

\section{INTRODUCTION}

Bottom sediments are naturally connected with water body of the river and it is essential in pollutant balance. Natural phosphorus cycle in water environment is sedimentation cycle. Once introduced to water ecosystem can be removed by different chemical, biological and physical processes and loses its environmental mobility as a sediment component. That immobility usually isn't permanent and in some cases phosphorus could be released from sediment what result with internal loading. Sediments buffer phosphorus concentration in water and as the result of concentration variability can decrease or increase aiming at equilibrium concentration [1]. Equilibrium concentration depends on many factors including dissolved oxygen conditions, $\mathrm{pH}$ and temperature [5]. Increasing of intensity of phosphorus releasing from sediment can take place in case of rapid changes of phosphorus content in water [10]. The example of such situation can occur in long-lasting raw wastewater receivers after reduction of contaminant load as a result of wastewater treatment plant operation [4]. 


\section{SITE DESCRIPTION}

Ner is small lowland river of $0.2 \mathrm{~m}^{3} \mathrm{~s}^{-1}$ natural flow. The city of Lodz discharges about 2.5 $\mathrm{m}^{3} \mathrm{~s}^{-1}$ of wastewater and for decades Ner was the receiver of $3-4 \mathrm{~m}^{3} \mathrm{~s}^{-1}$ raw wastewater [8]. Therefore the river average concentration of nitrogen amounted to $23 \mathrm{mgNdm}^{-3}$ and phosphorus $11.6 \mathrm{mgPdm}^{-3}$ (loads about: $3000 \mathrm{Mg} \mathrm{N}$ per year and $1500 \mathrm{Mg} \mathrm{P}$ per year respectively) [3]. In late ' 90 the treatment plant was started up and the water quality, however much better, still doesn't reach satisfactory level - most of chemical parameters remain high and the water is still classified in 5 - the worst quality range.

Among the conditions influencing the water quality in degraded wastewater receivers, internal and external factors should be pointed out. Within the external factors the most important are wastewater discharge (wastewater - natural flow ratio) and technical infrastructure (river channelization, hydraulic constructions, valley irrigation system, and land use of the watershed). The main internal factors are ecological status, sediment re-suspension, contaminant releasing from sediment and oxygen condition.

\section{MATERIALS AND METHODS}

The analyse of water quality was based on National Water Monitoring System data. Samples of surface layer $(5 \mathrm{~cm})$ of river bed sediment was taken in 8 points: 2 upstream and 6 downstream the Lodz wastewater outlet. Phosphorus fractions and total phosphorus content was determined in laboratory using extraction method described by Psenner and Pucsko [12].

In batch experiment, five duplicate $5 \mathrm{~g}$ samples of sediment were prepared for each sampling point using $50 \mathrm{cl}$ solution of different phosphates concentration to examine the equilibrium phosphate concentration (EPCo). It was tested and calculate according method described by Hause and Denison [11].

\section{RESULTS AND DISCUSSION}

In studied case the contaminants load was radically reduced by construction of wastewater treatment plant in city of Lodz. But the water quality improvement was not commensurate to this reduction. Such situation could be the result of increased phosphorus release from sediments deposed in the course of decades in river bed. On the distance the phosphate concentration increases up to $25 \mathrm{~km}$ downstream the WWTP outlet and it can not be explained by other pollution sources. The phosphorus content in the sediment is as high as 27 $\mathrm{mg} \mathrm{kg}{ }^{-1} \mathrm{dw}$. The equilibrium phosphate concentration experiment showed that it could be released to water body. The preliminary results showed that EPCo value exceed in some points limit of $\mathrm{V}$ (the worse) polish water quality norm and amount to $1.2 \mathrm{mg} \mathrm{PO}_{4} \mathrm{dm}^{-3}$ in oxic condition.

\section{CONCLUSIONS}

The division of main pollution sources into point and non-point seems to be uncompleted and should take into consideration bottom sediment - surface water interaction. This interaction usually marginal could became important, or even main factor in some cases during restoration of contaminated wastewater receivers [11]. And according to some researcher internal contaminant loading problem concerns not only phosphorus but also trace metals [7]. We should emphasize that the ratio of these processes is strongly related to oxygen condition 
so indirectly with organic matter content and BOD value [5]. Therefore this factors should be monitored and improved even if seems to be acceptable itself.

The internal loading could cause significant delay of water quality improvement after contaminant load reduction and because ecological conditions depends on the water quality, "good ecological status" could be reached many years after all proecological investments finalization.

Identification of all causes of bad river state during restoration planning could be essential because liquidation of main causes could uncover smaller, passed over reasons. And this reasons, treated as marginal before, could became critical factor in ecological restoration. Of course because of financial limitation we should begin with main problems solving. But if our goal is reaching "good ecological status" we shouldn't be surprised that liquidation of main pollution source are not sufficient especially when critical for ecosystem contaminants load has been exceeded multiple initially [8]. Research made on lakes showed that restoration requires not only time but also reaching much better water quality than was critical for beginning ecosystem collapse and degradation of the lake [6]. The similar effect, however it is unproved yet, could concern also highly degraded rivers and could be crucial to water quality and ecosystem restoration delay.

\section{REFERENCES}

[1] Froelich, P. N., 1988. Kinetic control of dissolved phosphate in natural rivers and estuaries: a primer on phosphate buffer mechanism. Limnol. Oceanogr. 33, 1542-1558.

[2] Hause, W.A., Denison, F.H., Factors influencing the measurement of equilibrium phosphate concentration in river sediments. Wat. Res. 34(4), 1187-1200

[3] Ilnicki, P., Banaszkiewicz, H., Bukowski, Ł., 2003. Żródła, stężenie i ładunki azotu i fosforu w wodach rzeki Ner. Formatio Circumiectus 2 (1), 23-34.

[4] Jappesen, E., Kristensen, P., Jenson, J. P., Søndergaard, M., Mortensen, E.. Lauridsen ,T.L., 1991. Recovery resilience following reduction in external phosphorus lading of shallow eutrophic Danish lakes: duration, regulation factors and methods for overcoming resilience. Memorie dell 'Instituto Italiano di Idrobiologia 48, 127-148

[5] Kim, L. H., Choi, E., Stenstrom, M. K., 2002. Sediment characteristics, phosphorus types and phosphorus release rates between river and lake sediments. Chemosphere 50, 53-61

[6] Lauridsen, T.L., Jeppesen, E., Søndergaard, M., 1994. Colonization and succession of submerged macrophytes in shallow Lake Vaeng during first five years following fish manipulation. Hydrobiologia 276, 233-242.

[7] Lau, S. S. S., Chu, L. M., 1999. Contaminant release from sediments in a coastal wetland. Wat. Res. 33(4), 909-918.

[8] Mosiej, J., 1999. Przyrodniczo-techniczne uwarunkowania gospodarowania woda w dolinie rzeki Ner. Rozpr. Nauk. i Monogr.(222) Wyd. SGGW: 1-155.

[9] Raport o stanie środowiska w woj. Łódzkim, 2003. Biblioteka Monitoringu Środowiska.

[10] Sheffer M., 1998. Ecology of Shallow Lakes. St Edmundsbury Press Ltd. London.

[11] Søndergaard, M., Kristensen, P., Jappesen, E., 1993. Eight years of internal phosphorus loading and changes in the sediment phosphorus profile of lake Søbygaard Denmark. Hydrobiologia 253, 345-356.

[12] Psenner, R., Pucsko, R., 1988. Phosphorus fractionation: advantages and limit of the method for study of sediment $P$ origins in and interactions. Arch.Hydrobiol.Beih.Ergebn. Limnol. 30, 43-59. 